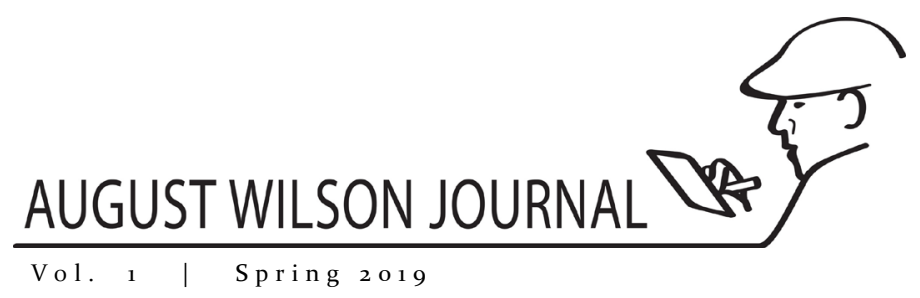

\title{
Stage Review of Gem of the Ocean
}

\author{
Round House Theatre; Bethesda, Maryland \\ November 28-December 30, 2018 \\ Directed by Timothy Douglas \\ By Leticia Ridley \\ Ph.D. Candidate, University of Maryland, College Park
}

The wooden planks that covered the stage, including the high ceilings and the back wall adorned with candles, captured the magnitude of its presence within the

community and the mysticism that sits inside of it.

$$
\text { - Leticia Ridley }
$$

\begin{abstract}
A review of August Wilson's Gem of the Ocean, staged at the Round House Theatre in Bethesda, Maryland, from November 28-December 30, 2018.

Keywords

August Wilson, Gem of the Ocean, Timothy Douglas, Goodman Theatre, Round House Theatre
\end{abstract}

Round House Theatre's production of Gem of the Ocean exemplified the brilliance, artistry, and significance of August Wilson's work in the American theater. Produced fifteen years after its original production at Chicago's Goodman Theatre, Gem resonated with American audiences, not only by artfully grappling with the effects of American Slavery and the unfulfilled promises of emancipation, but also by reminding us of the persistent ways that the law continues to overpolice and regulate Black life. Wilson's characters dramatize how African American history can simultaneously empower and confine the Black community, a sentiment best described by Solly Two Kings's question: "What is freedom if you can't do nothing with it?" Staged on a traditional proscenium, the production reinforced the audience's role as voyeurs of the lives of these characterscomplemented aptly by the historically credible costuming-that situ-

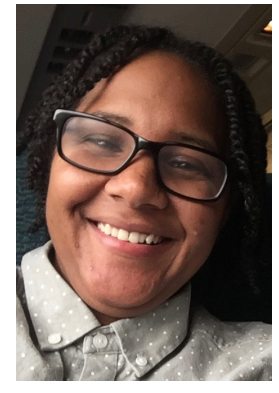

Leticia Ridley ated us to the post-emancipation era.

Under the direction of Timothy Douglas, a frequent director of Wilson's work (he has directed nine of Wilson's American Century Cycle plays at major US regional theatres), Round House's production captured the specificity and musicality in Wilson's rich dialogue. The lush language of Wilson became specifically activated during the scene where Citizen attempted to voice his attraction to Black Mary. As Citizen Barlow and Black 
Mary, Justin Weaks and Stori Ayers captured the texture of their characters. This could primarily be seen through Citizen's muttered and breathy speech or in Black Mary's swift and stoic responses to Citizen's words of affection.

The wooden planks that covered the stage, including the high ceilings and the back wall adorned with candles, captured the magnitude of its presence within the community and the mysticism that sits inside of it. Douglas also masterfully grasped the camaraderie among these characters and the refuge that they take with one another, capturing an important implicit claim of Gem: that sanctuary is not merely a physical, but is also a community of people. This is best reflected in the action taken collectively by the residents and visitors of the house to help Solly escape from Caesar. While the production represented the largeness of 1839 Wylie Avenue through its design choices, the direction solidified the notion that Aunt Ester's home is not entirely immune from the intrusion of outside forces. Instead, it is the relationships built inside of the house that protect its residents. Solly, played charismatically by Alfred Wilson, showed this most explicitly. Alfred Wilson infused Solly with humor and conviction. Recounting his and Eli's past helping runaway slaves on the Underground Railroad, Wilson hit the gravity of this horrific history of American enslavement while also maintaining the play's comedic moments.

The antithesis to Solly is Caesar Wilks, the proclaimed "boss man" of the Hill District. KenYatta Rogers' embodiment of Caesar reflected the intensity of the character. Each movement and action made by Rogers offered access to the interiority of Caesar. The rigid and upright posture of Rogers throughout the performance magnified the authority that Caesar feels he must enforce in order to lift himself above others. Rogers imbued Caesar with complexity, a difficult feat for the antagonist of the play. Douglas's direction, alongside the other production elements such as Kasey Hendricks' props, reinforced the idea that the interconnectedness of the lives of these characters cannot be separated from one another. For example, Solly's walking stick is introduced as an aid to help Solly get around and an instrument to avoid captivity by Caesar. But it serves its most significant function as Citizen assumes the walking stick after Solly's death, signaling his deliberate choice to carry Solly's legacy. Each prop designed by Hendricks was impressively incorporated into the production.

Throughout the play, Wilson conjures ancestral links through the figure of Aunt Ester (whose name, as critics often point out, conjures the sound of "ancestor"). The success of any production of Gem relies on the dynamic portrayal of Aunt Ester, a demand that actress Stephanie Berry fulfilled, if not exceeded. Berry's depiction embraced the assured ancestral knowledge with which Wilson infuses Aunt Ester, a wisdom she has gained from her experience of enslavement and African cosmology. Acting as an ancestral conduit and spiritual guide, it is only through Aunt Ester that Citizen Barlow can visit the City of Bones. Culminating the show's dramatic apex, Citizen's metaphysical journey to the City of Bones was the stand out moment of the production. Under the thoughtful direction and choreography of Douglas, the quaint kitchen/dining area (designed by Tony Cisek), became engulfed in ethereal, blue light (designed by Andrew R. Cissna), while Black Mary, Eli, and Solly sung (accompanied by original music of Justin Ellington) and served as witnesses and support for Citizen's journey. Weaks captured the pain in confronting and experiencing the harsh conditions of the Middle Passage. After Citizen confesses that he stole the nails, the stage illuminated with candles that had been out of site for the majority of the performance as he experienced the reverence and beauty of the City of Bones. Engulfed with this new knowledge, Citizen's soul has been cleansed and he returned to the celebratory song of his fellow witnesses.

The Round House production of Gem of the Ocean revived the potent legacy of enslavement that continues to structure the life of Wilson's characters, a thread continued throughout his American Century Cycle. Moreover, Wilson's play has further resonance for our current political climate, one that has witnessed an ever-proliferating increase of 
violent, racialized attacks on Black people and other marginalized communities in the United States. Accordingly, Wilson's Gem of the Ocean offers us a timely instruction to take up the respective calls of our ancestors and continue to fight for Black liberation, freedom, and life.

\section{Works Cited}

Wilson, August. Gem of the Ocean. Theatre Communications Group. 2007.

\section{Author Bio}

Ms. Leticia Ridley is a Ph.D. student in Theatre and Performance Studies of University of Maryland, College Park. She is a playwright, dramaturg, and scholar with interests include Black theatre and Performance, American Popular Culture, and Black Feminism with an emphasis on the intersections of race, gender, class, and sexuality.

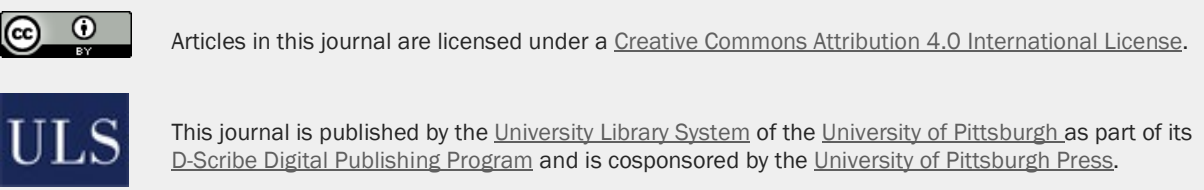

